\title{
Proportional analysis of façade openings on residential buildings from the Modernism Period by the architect Belobrk against the backdrop of bioclimatic architecture and current climate changes
}

\author{
V. Panic \& K. Bunjak \\ Faculty of Architecture, University of Belgrade, Serbia
}

\begin{abstract}
World policy has lately been increasingly geared toward current issues of limited energy resources and environmental crisis. Analyses have indicated that the built environment is the largest energy consumer and most hazardous gas emitter. Over the years, a whole range of recommendations and guidelines have been issued on building design. Nonetheless, the wider and more important question is the position of existing buildings (designed in accordance with local, natural and social determinants or not) at the time of climate change. The subject matter of this paper is the proportional analysis of facades and façade openings of residential buildings from Belgrade's Modernism period before the World War II (1930-1940). Buildings of this type represent the majority of the built environment in the city. A case study included three residential buildings by the architect Momcilo Belobrk at: 63 Njegoseva Str., 14 Dobracina Str. and 17 Dositejeva Str. Besides the direct proportional examination of the chosen buildings and their facades, potential connections with traditional proportioning principles have also been studied. The context and environment have been analyzed, and, primarily, the climate characteristics. This paper deals with exploring potential connections between the proportions of the façade openings and the natural conditions found at the locations. Subsequently, proportion and distribution of openings on façade shall be analyzed in the context of climate change. The analysis shall address the question of whether the building was designed in a way that enabled its openings' proportions to steam the climate and site characteristics. If yes, the question is how such a building behaves today,
\end{abstract}


considering all the evident climate and contextual changes? If not, how should we approach its renewal, obeying principles of bioclimatic architecture, and how to promote the architecture of Modernism in the present societal conditions?

Keywords: climate change, bioclimatic architecture, proportional analysis, Belgrade Modernism, Momcilo Belobrk.

\section{Introduction}

The main research theme of this paper is the proportional analysis of facades and façade openings of residential buildings from the Modernism Period in Belgrade in the decade before World War II (1930-1940), focusing on the work of the architect Momcilo Belobrk in the aspects of current climate changes and the proportions' impact on the elements of living comfort (temperature, daylight, natural ventilation). The research subjects are the following representative residential buildings located at: 63 Njegoseva Str., 14 Dobracina Str. and 17 Dositejeva Str. The research is mostly motivated by the fact that the residential buildings from the period of Modernism in Belgrade, most of which are protected by law, represent the majority of the built environment in the city. Therefore, in order to make a significant step towards a sustainable ecological city, it is important to start with the adequate and energy efficient reconstruction of these buildings.

Momcilo Belobrk, a Serbian Modernism architect, was born in 1905 in Valjevo, Serbia. He graduated at the Technical Faculty in Belgrade, Department of Architecture in 1930. At the beginning of his professional career he worked at the architect Djura Borosic's studio, where he designed, among others, the residential building at the corner of Njegoseva and Molerova Str. (63 Njegoseva Str.). First contacts with Purist and Modernism architecture came through exhibitions and lectures in Belgrade between 1929 and 1931 (The First Exhibition of Contemporary Yugoslavian Architecture in February of 1931, German Visual Arts Exhibition in April of 1931...). Belobrk also carefully studied the magazine 'Architecture' published in Ljubljana which had followed the contemporary architectural scene and avant-garde in Europe since 1929. In the year of 1928 a group of architects established the 'Group of Architects of the Modern Movement', known as GAMP with "the aim of propagating modern principles in architecture and applied arts" [1]. Momcilo Belobrk formally became a member of GAMP in 1932, as he confirmed in a later interview from 1980: "I have been accepted to the Movement after successful completion of the three-storey residential building at the corner of the Molerova and Njegoseva Str., or perhaps because of the appearance and modern proportions of the villa at the Vukice Mitrovic Str...." [2]. Architect Belobrk died in Belgrade in 1980. He had a significant influence on the architecture of Serbian Modernism, especially in Belgrade. Analysis of the selected residential buildings and their characteristics should, among the other more specific topics, show the architect Momcilo Belobrk's contribution to Belgrade's Modernism architecture, the development of his identity as an author, and his approach to the natural environment (climate characteristics) and socio-economic and urban context. 


\section{Research method}

The research proposed in this paper includes the comparative study of the socioeconomic and urban context, physical geography of the surroundings and climate conditions from the period when the works were created and today. The paper deals with exploring potential connections between the proportions of façade openings and the natural conditions found on the locations. Subsequently, proportion and distribution of the openings on façade shall be analyzed in the context of climate changes. The analysis shall address the question whether the building was designed in the way that enabled its openings' proportions to stem from the climate and site characteristics.

The main analysis included proportion study of the openings on façade (surface of openings, relation between length and width...) and façades as a whole (relation between one opening and the whole façade - rhythm, positions, distance...). Besides the direct examination of proportions on the chosen buildings' façades, potential connections with traditional proportioning principles will be studied. It is common knowledge that traditional architecture used the basic principles of bioclimatic architecture. Therefore, the potential relation with traditional proportioning principles may prove the willingness of architects of Modernism to design in accordance with the environment and climate.

\section{Discussion}

\subsection{Climate conditions in Belgrade, Serbia}

Due to its position, the city of Belgrade belongs to the temperate continental climate zone. Yet we know that cities have their own local characteristics that make them different from other non-urban territories. Local climate specificities of Belgrade are influenced by the topography, surface (rivers, soil, vegetation...) and city structure.

The most important climate elements that can be related to the proportions of building openings are temperature and dominant winds. In order to analyze climate conditions in Belgrade, Serbia along with their possible changes, and having in mind the usual yearly variability, the authors Ducic and Radovanovic have compared average climate data for the decades in period between 1891 and 2000. In this research we have added the data relevant to the last decade 20012010 (Table 1). Comparing the data, we can notice that the lowest decade temperatures were at the end of the $19^{\text {th }}$ and at the beginning of the $20^{\text {th }}$ century. The difference between decades with the lowest and highest temperatures (decade $1891-1900$ and decade $2001-2010)$ is almost $2^{\circ} \mathrm{C}\left(1.95^{\circ} \mathrm{C}\right)$. Along with the temperature rising, we can notice a slight precipitation rising as well (Figure 1). In order to follow temperature and precipitation changes most accurately, the World Meteorological Organization (WMO) suggested using a comparison of data based on meteorological periods of 30 years [3]. By doing so, we can notice that for the period 1891-1920 the average temperature was 
$11.20^{\circ} \mathrm{C}$ and the average precipitation was $631.7 \mathrm{~mm}$; for the period $1921-1950$ values for these parameters were $11.80^{\circ} \mathrm{C}$ and $676.0 \mathrm{~mm}$; for the period 1951$1980-11.80^{\circ} \mathrm{C}$ and $704.8 \mathrm{~mm}$; and for the period $1981-2010-12.55^{\circ} \mathrm{C}$ and $691.0 \mathrm{~mm}$. The absolute temperature maximum was recorded recently - in summer of 2007 the temperature was $43.6^{\circ} \mathrm{C}$. The maximum before that was recorded back in 1988 and had a value of $40.2^{\circ} \mathrm{C}$. The absolute temperature minimum for the territory of Belgrade was $-21^{\circ} \mathrm{C}$ (1966). By observing all these data we may conclude that in the course of time, the climate in Belgrade has become warmer and wetter.

Table 1: Decade temperatures $\left[{ }^{\circ} \mathrm{C}\right]$, perception $[\mathrm{mm}]$ and population in Belgrade for the decades between 1891 and 2010 [3].

\begin{tabular}{|c|c|c|c|}
\hline Декада & Temperature $\left[{ }^{\circ} \mathrm{C}\right]$ & Precipitation $[\mathrm{mm}]$ & $\begin{array}{c}\text { Population at the beginning of the decade } \\
\text { [in thousands] }\end{array}$ \\
\hline $1891-1900$ & 11,17 & 651,9 & 44 \\
\hline $1901-1910$ & 11,24 & 591,6 & 64 \\
\hline $1911-1920$ & 11,27 & 651,5 & 84 \\
\hline $1921-1930$ & 11,74 & 620,7 & 135 \\
\hline $1931-1940$ & 11,53 & 726,0 & 266 \\
\hline $1941-1950$ & 12,10 & 681,3 & 322 \\
\hline $1951-1960$ & 11,91 & 706,4 & 428 \\
\hline $1961-1970$ & 11,84 & 665,7 & 619 \\
\hline $1971-1980$ & 11,71 & 742,2 & 780 \\
\hline $1981-1990$ & 11,99 & 645,7 & 1092 \\
\hline $1991-2000$ & 12,55 & 677,1 & 1171 \\
\hline $2001-2010$ & 13,12 & 750,1 & 1576 \\
\hline
\end{tabular}

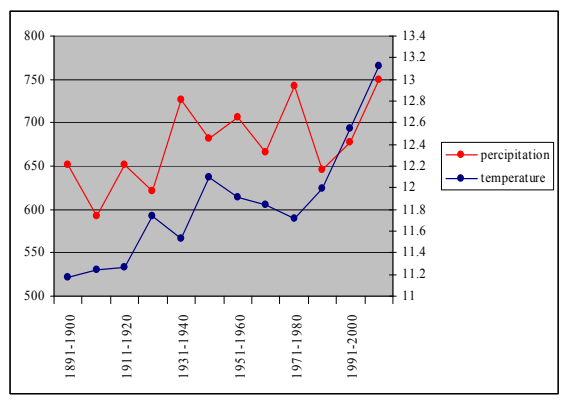

Figure 1: Decade temperature and precipitation change for Belgrade, Serbia.

Still, it is necessary to point out that the given data for Belgrade are not entirely accurate due to the existence of an urban heat island. It is common knowledge that the process of urbanisation changes thermal characteristics of the surroundings. By comparing data from Belgrade and from a location close to the city, but in a non-urban environment, Ducic and Radovanovic, have concluded 
that the rising value of the urban heat island is influenced by the process of urbanisation and related to the population increasing.

The other climate element relevant to this research is the wind (Table 2). By analysing the data, we can notice that the strongest and the most frequent wind in the territory of Belgrade is the one that blows from the south-eastern (SE) direction-named "kosava". Another dominant wind in Belgrade blows from the west-southwest (WSW) direction and it is called "gornjak". Again, depending on the urbanisation level and type and city structure, wind influences can be more or less relevant.

Table 2: $\quad$ Average wind frequencies and silence (c) [\%o] and wind speeds [m/s] for Belgrade, Serbia [4].

\begin{tabular}{|c|c|c|c|c|c|c|c|c|c|}
\hline City & $\mathbf{N}$ & $\mathbf{v}$ & $\mathbf{N E}$ & $\mathbf{v}$ & $\mathbf{E}$ & $\mathbf{v}$ & $\mathbf{S E}$ & $\mathbf{v}$ & $\mathbf{C}$ \\
\hline \multirow{3}{*}{ Belgrade } & 75.5 & 2,6 & 45,5 & 2,1 & 109 & 2,6 & 251 & 2,6 & \\
\cline { 2 - 11 } & $\mathbf{S}$ & $\mathbf{v}$ & $\mathbf{S W}$ & $\mathbf{v}$ & $\mathbf{W}$ & $\mathbf{v}$ & $\mathbf{N W}$ & $\mathbf{v}$ & 8 \\
\cline { 2 - 10 } & 67,5 & 2,2 & 81,5 & 1,9 & 156 & 2,4 & 126 & 2,6 & \\
\hline
\end{tabular}

\subsection{Socio-economical and urban context}

Development of the culture, art and architecture in period between 1920 and 1940 was generated by influences of French and Russian traditional expression and also by collaboration with a newly established country - Czechoslovakia. In this period between the wars, socio-political conditions and key events in contemporary cultural discourse opened the way for the new modern art and avant-garde in the Kingdom of Yugoslavia. This is the time when Belgrade started rapidly to change its appearance. From a small town with around 120,000 inhabitants in 1919 and mostly one-storey houses, it developed into the capital city with more than 320,000 inhabitants at the dawn of World War II. In the process of creating a new contemporary cultural identity and besides all economical and social problems, Serbia and Yugoslavia partly implemented Modernism into their socio-cultural habitat. By observing the city we can notice that during the thirties' residential houses were more likely built according to the principles of Modernism than in the neoclassicism and secession style. This was the original context and framework within which selected buildings were created.

Since then political, socio-economical and therefore urban context changed significantly. The process of urbanization and city growth continued. Destruction during and the process of rebuilding after World War II and NATO bombing in 1999, largely changed the city appearance. At the same time, the population grew rapidly due to migration from rural areas and an increasing number of war refugees. According to the latest census data, Belgrade's population in 2011 was $1,639,000$, six times larger than at the beginning of the decade 1930-1940 (266,000 people). Along with the population increasing and economical crises, prices of building land in the city have risen as well. This led to the rapid replacement of one-storey houses and the fast construction of new, multi-storey buildings. Currently, there are more than half a million vehicles in the city and 
the pollution level constantly rises. Context and natural conditions of selected buildings have changed drastically. Were the buildings of Modernism constructed according to the natural conditions and immediate context and how do these buildings behave today?

\subsection{Proportional analysis of the selected buildings}

Momcilo Belobrk's residential buildings were built on the model of European Cubism and Purism. The main purpose of his architecture without ornaments is to point out primer shapes of form and architecture plastic. By functional organization of the space, apartment units were rationally defined and derived from the distribution of façade openings. Buildings are clear, pure and comprehensible in their materialization and proportion. These objects, built in the context of smaller houses from period of the $19^{\text {th }}$ century Academicism and Classicism, represented Serbian architecture, Modernism, in the third decade of the $20^{\text {th }}$ century with their pure expression.

As a main proportional system and primary module for defining openings in relation to the whole façade and for defining dimensions of a window itself, Belobrk used the golden ratio. Window proportions - relations between height and width - were created in the range of between 1:1.6 and 1:1.8, depending on the specific utilization of indoor space.

\subsubsection{Residential building at 63 Njegoseva Street}

Momcilo Belobrk designed the building at 63 Njegoseva Street at the beginning of his professional career within the Djura Borosic's studio. The building was positioned at the street corner and finished in 1932. It represents one of the first examples of purist residential building designs in Belgrade. In the opinion of architecture historian Zoran Manevic here it is possible to sense connection between the early Modernism principles and methods of the late Modernism seen in the rounded form in the attic and in the clear division of full and empty surfaces (window openings in the clear proportional façade division) [4] (Figure 2).

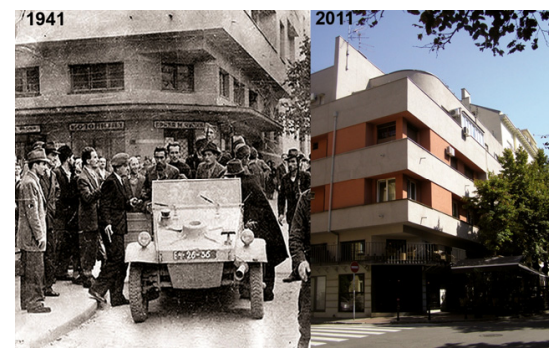

Figure 2: Residential building at 63 Njegoseva Street, architect: Momcilo Belobrk, year: 1932.

The building context changed during the decades. Small, one-storey houses were replaced with higher ones, but since the street is wide enough, influence on 
the Belobrk's house remained minimal - they do not shade the object and provide additional wind protection.

The building is situated at the corner of Njegoseva and Molerova Street. The façade from Njegoseva Street is south-west orientated, while the other one, from Molerova Street, has a north-west orientation. It is well known that the southnorth house position is the most appropriate for temperate climates. Rotating the house position slightly towards the west in Belgrade has a deeper meaning. In order to protect them from energy losses during the wind periods and still provide adequate natural ventilation, the best building position is parallel to the dominant wind directions. One of the dominant winds "kosava" blows from south-east to the south-west (parallel to the façade looking to Molerova Street), while the other "gornjak" blows from west-southwest to east-northeast direction (almost parallel to the façade from Njegoseva Street). Newer higher buildings in the surroundings and the trees planted along the Njegoseva Street provide additional wind protection.

Disposition of the rooms inside and windows on the facades clearly respect natural conditions. Most of the living rooms and bedrooms are positioned on the south-west façade, while the services (bathrooms, keeping rooms etc.) are oriented towards a courtyard. The most suitable positions for the terraces are east, south-east, south and south-west. Following this, the majority of terraces are positioned on the south-west building façade. In order to use advantages of favourable solar radiation as much as possible, Belobrk created corner terraces indrawn towards the inside. In drawing corner terraces and most of the windows on the south-west façade, Belobrk prevented summer overheating and at the same time, provided the necessary amount of daylight. In the project wooden blinds on the windows were also designed as an additional protection against summer overheating. During the winter period indrawn windows allow the sun's rays to penetrate deep into the room (Figure 3).
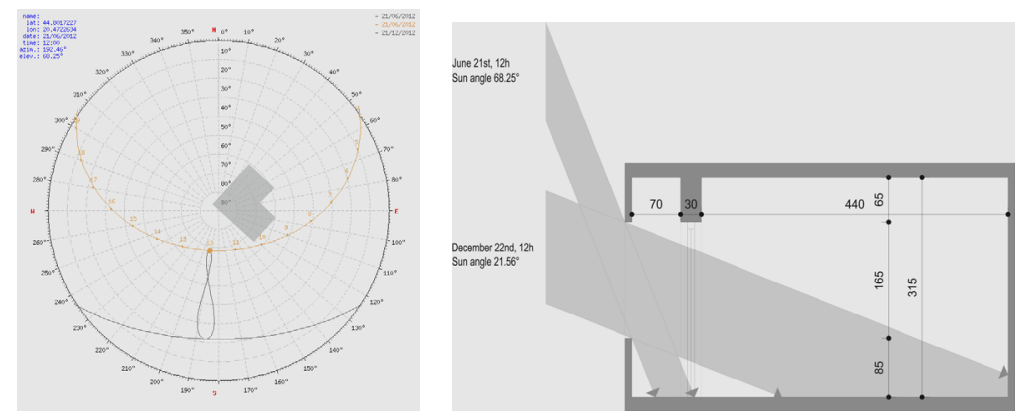

Figure 3: Left - sun path diagram with the position of the building; right direct sunlight entrance for typical room of building in Njegoseva Street on December $22^{\text {nd }}$ and June $21^{\text {st }}$

A proper amount of daylight and sun radiation depends on the size and proportion of windows and glass surfaces. Although demands for daylight remained the same, after 1995 world standards and regulations became stricter, 
which implies that only the precise and proper design can reconcile these two demands - maximum allowed window size (due to energy efficiency) and the need for an adequate amount of daylight. The maximum permitted glass surface for residential buildings, according to the present regulations, is $30 \%$ of total façade surface. By calculating the glass surface at this residential building we can notice that it does not exceed these $30 \%$ - window surface on the northwest façade represents $22.6 \%$ of the whole façade, and on the south-west façade $25.5 \%$ (figure 4). A larger percentage of glass area on the south-west façade corresponds to the daylight demands and orientations. The most common method for defining appropriate glass area is by using the floor area. In the world's regulations, the window surface should be a minimum of $10 \%$ of the floor area in the room. A typical room in this building has an area of approximately $20 \mathrm{~m}^{2}$, and the corresponding window area of app. $3.5 \mathrm{~m}^{2}$ (around $17.5 \%$ of the floor area).

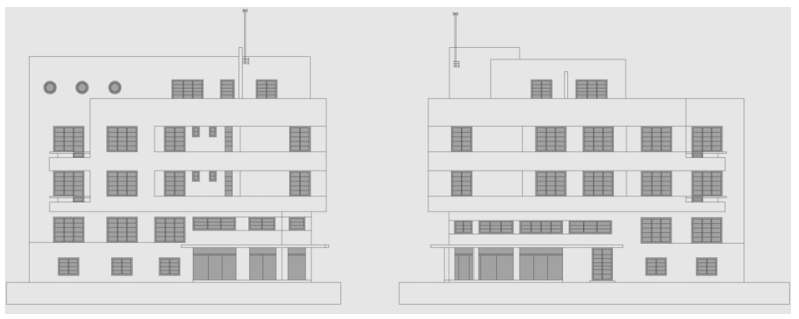

Figure 4: Percentage of façade openings, residential building at Njegoseva 63.

The window opening has a proportional relation 1:1.2 and in regard to the total façade area they have rhythmical disposition of the modules $a / b$ both in vertical floor division and in horizontal interspaces of windows and terraces (Figure 5 right). Golden ratio proportion appears in the analysis of the whole facades and it is derived from the multiplication of a square grid and tripartite façade division (Figure 5 left).

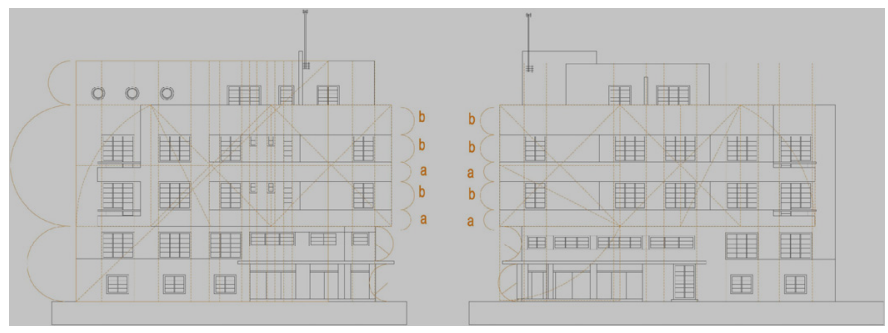

Figure 5: Residential building at 63 Njegoseva Street, proportional analysis (north-west and south-west façade).

\subsubsection{Residential building at 14 Dobracina Street}

This five-storey residential building is situated on the street corner and at the time of construction it dominated with its form in the immediate urban context 
(Figure 6). Like in the other Belobrk's residential buildings, we can notice here as well the harmony of openings and their division and disposition, rounded corner façade wall and indrawn terraces as an element of direct sun protection. With elements of Functionalism and Modernism (rounded windows, mast, ribbon windows) and with careful grading of façade planes, this object has all the components of a proportional Modernistic façade, but in a context of traditional proportional systems and traditional architecture.

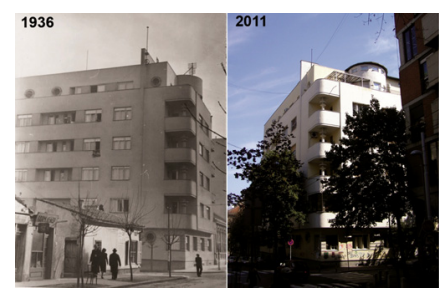

Figure 6: Residential building at 14 Dobracina Street, Momcilo Belobrk, 1936.

Belobrk orientated most of the rooms towards south-west. For those apartments where the plot disposition had not allowed this, he used north-west orientation. At these apartments he used an inner courtyard façade (south-east) for gaining additional light and for the most proper orientation of kitchens, dining rooms and terraces.

Window openings are in the proportional relation $b / c=1: 1.333$ and in the regular grid derived from the area of square that includes the whole north-west façade. An inscribed rectangle is formed from this square by using the golden ratio. This rectangle geometrically and functionally corresponds to the area of the first four floors. This proportion further generates a rhythm of openings $a / b$ where $a$ is the distance between windows and $b$ the height of the openings in the vertical regulation of the building. (Figure 7 left). The south-west façade has translated a golden ratio rectangular in the proportion of the basic façade area. We can notice here that author used dimensions of the height and horizontal regulation of the plot to determine dependency between two facades, thus forming volumes of Modernistic building in a spirit of traditional search for the golden ratio (Figure 7 right). The proportional image of the tripartite façade

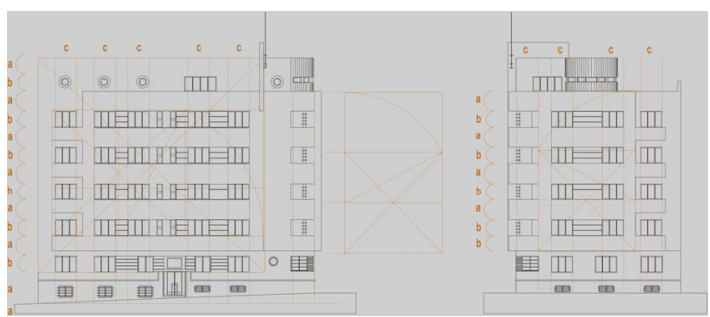

Figure 7: Residential building at 14 Dobracina Street, proportional analysis. 
division that has its esthetical and geometrical roots in ancient architecture has been additionally outlined by drawing in the façade of the last floor.

Calculations of the glass surface in the case of this residential building have shown that the area of openings again does not exceed those $30 \%$ - window surface on the north-west façade represents $16.4 \%$ of the whole façade, and on the south-west façade $17.0 \%$ (Figure 8 ). We can also notice the slight increase of glass surface on the south-west façade.
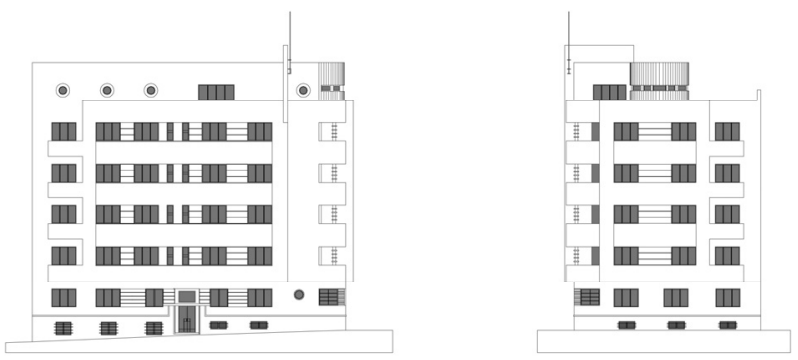

Figure 8: Percentage of façade openings, residential building at Dobracina 14.

A typical room in this residential building has an area of approximately $21.2 \mathrm{~m}^{2}$ and window surface of app. $3.5 \mathrm{~m}^{2}$. The glass area is therefore around $16.5 \%$ of the floor area and corresponds to present design standards. The only protection from direct sun is the wooden blinds. Still, the position of the windows and their proportions allow deep penetration of direct sun during the winter period, and a minimal amount of direct sun during the summer months by which the overheating is prevented (Figure 9).
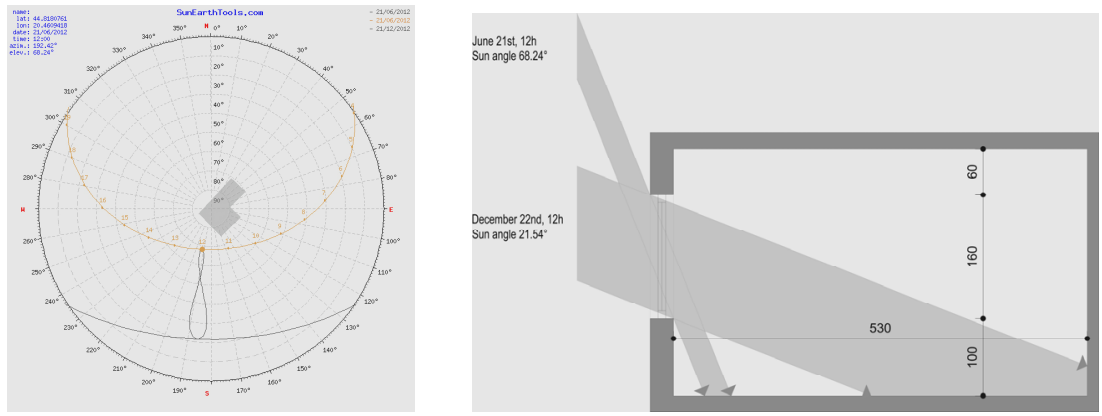

Figure 9: Left - sun path diagram with the position of the building; right direct sunlight entrance for typical room of building in Dobracina Street on December $22^{\text {nd }}$ and June $21^{\text {st }}$

The urban context of this building had changed drastically. Originally surrounded by one-storey family houses, this building stands today in a completely different environment of five and six-storey structures. Both streets are not wide enough to provide the same quality of light as they once did. High 
structures and trees today create the shade, especially on lower floors. This can be observed in particular during the winter months, when the sun is low. Although trees and shades from surrounding objects prevent summer overheating, the building receives today considerably less solar radiation during the winter.

\subsubsection{Residential building at 17 Dositejeva Street}

This six-storey residential building is also situated at the street corner and, like the others, has all the specificities of Belobrk's Modernistic architecture harmony of window openings, rounded corner wall, indrawn terraces, etc. (Figure 10).

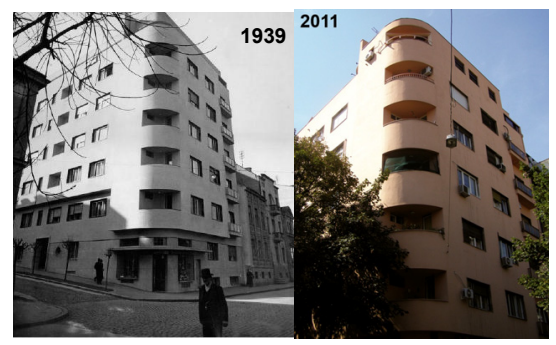

Figure 10: Residential building at 17 Dositejeva Street, architect: Momcilo Belobrk, year: 1937.

The building has south-east and north-east orientated façades. Most of the rooms (living rooms, bedrooms, etc.) have a south-east orientation. Belobrk placed all services (bathrooms, kitchens, building staircases, etc.) on the internal, courtyard north-west façade.

Unlike the other two examples, this building is specific in using golden ratio proportions not only for forming the whole façade, but also for defining the window dimensions in the relation 1:1.6. As a result of this, the author achieved harmonious rhythm between window opening and the whole façade and logical dispositions of the room functions inside. The south-east façade is derived from the relation between square and one-third of the square (façade in the relation $4: 3)$. On this façade one-third of the square is used for height regulation of the central building part (1-5 floor) forming the relation $1 / 3+1 / 3+1 / 3$ in height and $4 \times 1 / 3$ in width (Figure 11).

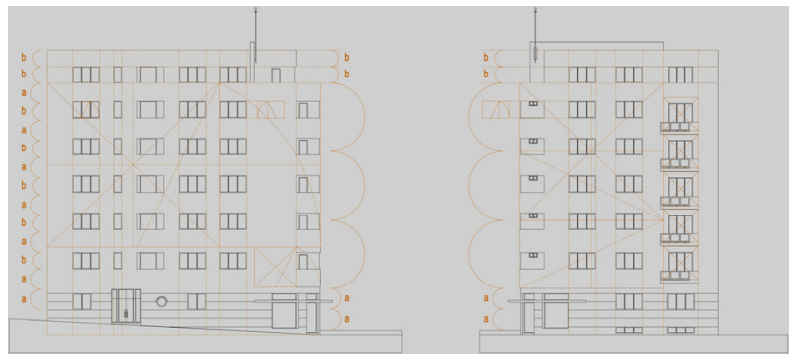

Figure 11: Residential building at 17 Dositejeva Street, proportional analysis. 
Belobrk uses here indrawn corner terraces and wooden blinds as well, being aware of the possibility of overheating during the summer period. The glass surface is again below $30 \%-18.6 \%$ at the south-east and $20.40 \%$ at the northeast façade (Figure 12). The window surface is again around $16-17 \%$ of the floor area in the room (Figure 13).
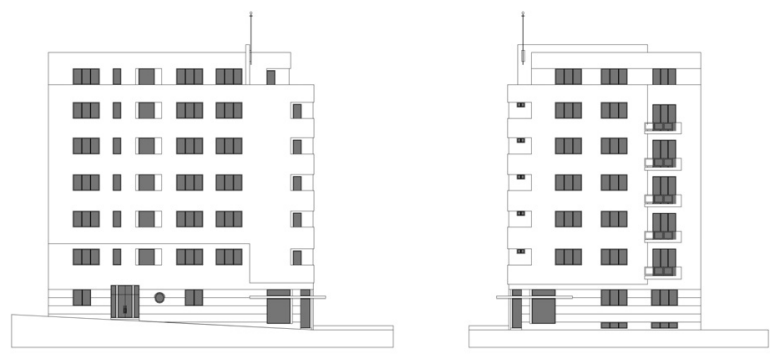

Figure 12: $\quad$ Percentage of façade openings, residential building at Dositejeva 17.
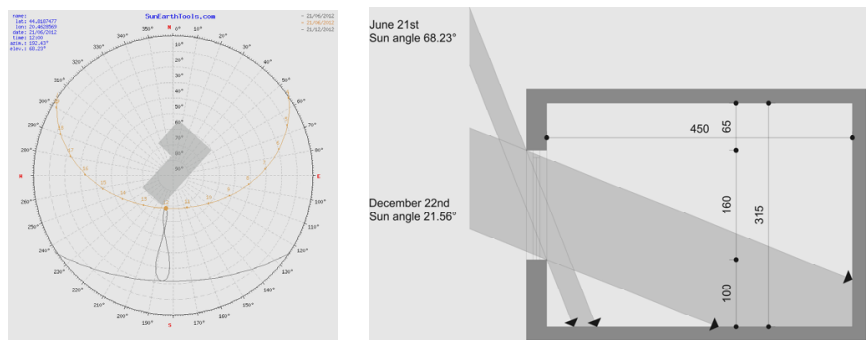

Figure 13: Left - sun path diagram with the position of the building; right direct sunlight entrance for typical room of building in Dositejeva Street on December $22^{\text {nd }}$ and June $21^{\text {st }}$

As the building is situated in the old part of Belgrade, most of the original one-storey houses are still creating the immediate context. Vegetation is one of the few context changes and helps in preventing summer overheating.

\section{Results and conclusions}

It is common knowledge that traditional architecture throughout history followed local environmental conditions and that traditional architects designed according to them. Pioneers of Modernism embraced social reforms related to the new man in the industrial society and technological progress brought by industrial revolution and scientific discoveries. With the new man came the new needs, so architecture turned to form and functionalism. The architecture of Modernism widely accepted the new Le Corbusier's proportional system known as Modulor. On the other hand, it is also known that architects of Modernism learned from their traditions and knew how to adapt and apply that knowledge within the new modern reality. In his text "Integrating the Modulor into International Modular System", Serbian Modernist, architect Milan Zlokovic noticed that the core of Modulor is 
represented by two interconnected sequences of longitudinal measurements based on the traditional golden ratio division. As a start measurement Le Corbusier took the human height ( 6 feet $=72$ inches $=1.829$ meters $)$ and divided it by using the golden ratio. Adopting 72 inches as a human height, instead of the previous 1.75 meters, Le Corbusier used the numbers of the Fibonacci sequence, connecting the Modulor more with traditional systems of proportioning. [5]

A conducted analysis of the three representative residential buildings from the Modernism Period in Belgrade by Momcilo Belobrk showed that, although designed in the spirit of the New architecture, facades were formed by using traditional systems of proportioning. Besides demonstrating that Modernistic aesthetics can be generated from traditional principles, this analysis also proved that the buildings were initially designed according to the immediate local context. Proportions, sizes and dispositions of the façade openings, dependent form the local conditions, were created in such a way as to provide necessary daylight and ventilation for each specific function. During the decades, climate and local context of the buildings have changed. The climate in Belgrade has become warmer and wetter, and passive designed systems used in creating these buildings have considerably lost their effectiveness. Simple wooden blinds can no longer provide efficient protection from summer overheating, and replacement of the surrounding one-storey buildings with higher ones has mostly prevented penetration of the sun during the winter months.

Since buildings of this kind - residential Modernistic buildings - represent the majority of the built environment in Belgrade, it is necessary to start with their careful reconstruction, taking into consideration the design methods used by their architects, present climate change, as well as the changes of other local characteristics.

\section{Acknowledgement}

This paper was realized as a part of the project "Studying climate change and its influence on the environment: impacts, adaptation and mitigation" (43007) financed by the Ministry of Education and Science of the Republic of Serbia within the framework of integrated and interdisciplinary research for the period 2011-2014.

\section{References}

[1] Kojić, B., Društveni uslovi razvitka arhitektonske struke u Beogradu 19201940. godine. Beograd: SANU Odeljenje društvenih nauka i umetnosti, knjiga 81, 1979.

[2] Vukotić, L., Vukotić, M., "Momčilo Belobrk". Edicija: Srpski arhitekti novijeg doba. Beograd: Muzej nauke i tehnike, 1996.

[3] Ducić, V., Radovanović, M., Klima Srbije. Beograd: Zavod za udžbenike i nastavna sredstva, 2005.

[4] Manević, Z. "Momčilo Belobrk”. Izgradnja, 8(81), Beograd, 1981.

[5] Zlokovic, M. "Divina Proportio $\neq$ Sectio Aurea". Pregled arhitekture, ed. Dj. Petrovic, br. 4-5 (1955-1956), 1960. 